\title{
A revisão do conceito de populismo por Ernesto Laclau: estratégias para a criação de um povo
}

\section{Samuel Martins dos Santos}

Mestre em Filosofia do Direito pela Universidade Federal de Santa Catarina (UFSC), Docente da Faculdade CESUSC, Florianópolis, SC, Brasil

samuelmartinsdossantos.1977@gmail.com
LACLAU, E. A razão populista. São Paulo: Três Estrelas, 2013.

A elaboração das Teorias Democráticas contemporâneas mudaram de forma substantiva a formulação sobre a origem do poder, sobretudo, ao deslocar a origem da soberania divina para a soberania popular.

Se a formula que dispõe que todo o poder emana do povo é sucinta, sendo introduzida amplamente nas Constituições dos Estados Nacionais do ocidente a partir do século XVIII, a instauração de um regime político com estas características demonstrou-se mais complexa do que a formalidade jurídica poderia supor.

Enquanto os séculos XVIII e XIX inauguraram regimes democráticos com eleitorados razoavelmente pequenos, a grande novidade do século XX para o Direito Constitucional e para a Ciência Política foi a ampliação em larga escala do direito ao voto e, consequentemente, do eleitorado.

A expansão de um sistema institucional de representação política neste período foi, e ainda é, uma grande questão a ser equacionada. Isto porque a Teoria Política Liberal concebeu a configuração do Estado Democrático de Direito como uma relação entre governantes/governados a partir dos critérios da racionalidade moderna. Nesta perspectiva, o exercício da soberania por parte do povo decorria da ação política de cidadãos racionalmente determinados e comprometidos com um ciclo virtuoso de um bom governo.

Todavia, tanto na Europa quanto nas Américas a ampliação do número de eleitores ensejou questionamentos sobre a manutenção da racionalidade como intermédio nas relações entre governantes e governados.

O desencatamento entre a expectativa de um povo formado por cidadãos racionais à sua concepção como uma massa ignara ensejou analises negativas, com a indicação de que um grande número de eleitores dificilmente conseguiria manter padrões elevados de racionalidade em processos eleitorais de extensa base eleitoral.

Tradicionalmente os governos caracterizados por grandes contingentes eleitorais e lideres carismáticos que estabelecem uma relação direta com o povo foram adjetivados como governos populistas. Atualmente o conceito de populismo tem passado por um rigoroso revisionismo, neste contexto Ângela de Castro Gomes (1996) indica a grande dificuldade de sua definição, como também a sua inexatidão para classificar regimes políticos específicos. 
Nesta seara a obra A Razão Populista do argentino Ernesto Laclau contribui com uma revisão bibliográfica e com a apresentação de elementos para uma revisão substantiva do conceito de populismo. O autor não tem absolutamente nenhuma precipitação na conceituação do que ele entende por governos populistas, ou a razão populista, que dá nome ao livro (LACLAU, 2013).

Todavia, desde o início do trabalho o autor deixa claro o seu afastamento de uma interpretação que fez escola no Brasil, que indica o populismo como uma ideologia, um regime político de um recorte histórico específico, ou apenas uma relação direta entre governados e um líder carismático.

A primeira diferenciação neste sentido ocorre quando Laclau indica a busca por parte dos estudiosos de conceitos com conteúdos fixos e definíveis referentes ao populismo. A partir das dificuldades para a implementação deste objetivo e da verificação da multiplicidade dos conceitos que compõem a temática do populismo estes estudiosos concluem pela sua característica negativa, como um fenômeno de embuste e subversão do eleitorado, sendo irracional e de caráter transitório.

Enquanto estudioso da teoria do discurso, o autor não concebe as indefinições conceituais de forma negativa, e também se afasta da busca de enquadramentos restritos do fenômeno do populismo.

Inicialmente, o autor apresenta duas perguntas básicas. Primeira, a busca de uma racionalidade conceitual não seria responsável pelo afastamento por parte dos pesquisadores do que o populismo tem de mais característico? Segunda, em vez de questionar a vagueza e imprecisão do conceito de populismo não seria mais pertinente reconhecer que a realidade social, em algumas situações, é também vaga e indeterminada?

Com estas duas perguntas o autor muda a perspectiva epistemológica de análise, os processos políticos denominados de populistas não são falhos em função da inexistência de uma doutrina racionalmente perfeita para explicá-los, pelo contrário, a sua incompletude conceitual não é uma falha, pois se trata de uma adaptação para fenômenos históricos distintos entre si, que contêm semelhanças em suas estruturas discursivas.

Segundo Ernesto Laclau a razão populista é uma lógica política que não se restringe geograficamente, nem cronologicamente. Na primeira parte do livro, o autor faz uma revisão bibliográfica sobre o pensamento político entre os séculos XIX-XX, marcando de que modo a atuação política daqueles grupos que não compunham tradicionalmente a esfera institucional é interpretada como uma forma negativa de política.

Na análise da obra de Gustave Le Bon, denominado de um novo Maquiavel, Ernesto Laclau se afasta de uma interpretação apenas critica, para enfatizar quais os mecanismos ali expostos que se apresentam como úteis à condução de grandes grupos eleitorais.

Diferentemente de Freud, Gustave Le Bon não se preocupa com as relações internas entre os discursos produzidos por grupos específicos, mas sim em indicar as características da sua composição externa, que podem ser absolutamente arbitrárias, e a psicologia das massas. A racionalidade lógica, portanto, não é um critério de eficiência do discurso para Gustave Le Bon.

Neste contexto destaca-se a figura de linguagem metáfora que possibilita a elaboração de comparações entre dois elementos distintos dos discursos e, muitas vezes, absolutamente desconexos entre si. Ernesto Laclau aponta que a metáfora possui um grande potencial discursivo em função da sua possibilidade de aproximação dos mais distintos elementos.

Assim, as equivalências entre objetos distintos entre si, que poderiam ser concebidas como uma deficiência do discurso, ganham importância pela sua eficiência em alcançar a compreensão do conteúdo por parte de um maior número de pessoas.

Outra estratégia apontada por Laclau em Gustave Le Bon é a repetição, com o destaque para o fato desta estratégia compor visões de mundo e moldar comportamentos sociais. Entre criticas e análises à Gustave Le Bon, Ernesto Laclau aponta dois pressupostos principais que marcaram esta primeira fase da psicologia das massas: o fato das linhas divisórias entre as formas racionais da organização social e dos fenômenos de massa coincidir, em grande medida, com a fronteira que separa o normal do patológico; e a distinção entre racionalidade e irracionalidade coincidir amplamente com a distinção entre o indivíduo e o grupo.

Estas duas passagens do racional para o irracional, e do indivíduo para o grupo, foram apresentadas neste primeiro momento como responsáveis pela denigração das massas.

Continuando a revisão bibliográfica, o autor analisa Hyppolyte Taine e Gabriel Tarde, neste ultimo destaca um depuramento em relação ao trabalho de Gustave Le Bon, no que diz respeito a sugestionabilidade, que é destacada como um elemento de discursos propositalmente incompletos nos quais a sugestão tem uma função de referência explicativa a ser integrada pelo ouvinte, sem detalhamento por parte do emissor, e também exerce a importante função interespiritual, intermental e interpsicológica, na relação entre governantes e governados.

Ernesto Laclau apresenta a seguinte pergunta: por qual motivo estes autores fracassaram nas suas análises dos movimentos da psicologia das massas? A resposta mais uma vez indica o que há de novo no trabalho de Laclau, segundo o qual um forte viés antipopular das dicotômicas ortodoxas e estéreis 
explicam a limitação das análises destes autores como, por exemplo, individuo/multidão; racional/irracional; o normal/patológico.

No entanto, ao evitar os perigos da ortodoxia o texto enfatiza que os autores estudados não se referem, necessariamente, a processos patológicos. E que a possibilidade de compreensão destes fenômenos, inclusive, para a compreensão da psicologia individual será melhor desenvolvida por Sigmund Freud, que ao invés de analisar momentos conturbados de irrupção revolucionária, enfocará movimentos perenes de massa como o Exercito e a Igreja.

Uma mudança identificada na obra de Freud é o rompimento dos paradigmas binários que marcavam a psicologia das massas até então, outro aspecto que merece destaque é a análise que o mesmo faz das relações internas entre os membros do grupo e suas lideranças.

Neste aspecto a constituição de um laço libidinal vai possibilitar a identificação entre os membros do grupo, a partir da substituição do Eu, ou o Ideal do Eu, pelo objeto que serve de união desta coletividade específica e que é introjetada no indivíduo.

Na interpretação de Laclau sobre a obra de Freud, o laço libidinal e a introjeção do objeto da coletividade no Eu serão responsáveis pela subserviência dos governados em relação aos governantes, como também pela coesão que é característica os membros destes grupos.

Ernesto Laclau expressamente adota a perspectiva de Freud para os próximos capítulos, mas destaca que pretende evitar uma análise exclusivamente freudiana e valorizar a intertextualidade com várias matrizes do pensamento.

Nesta esteira, cinco elementos serão essenciais às analises desenvolvidas. Enfocando as relações internas que constituem o grupo, o autor destacará o que ele chama de relações de equivalência e relações de identidade. Em outro aspecto, particularmente no que se refere à análise do discurso, o autor destacará os significantes vazios e os significantes flutuantes. E, por fim, a heterogeneidade como elemento incontornável no desafio de fundo assumido por Ernesto Laclau, a análise das estratégias para a criação de um povo.

Enfocando aspectos internos entre governantes e governados, os dois primeiros elementos são desenvolvidos claramente como consequências das bases estabelecidas pelos estudos freudianos de Ernesto Laclau, o objetivo é demarcar quais os mecanismos ensejadores da formação de um grupo.

As relações de equivalência têm a função de identificar, ou criar, semelhanças entre os membros do grupo. Além de garantir coesão interna tal mecanismo possibilitará a demarcação dos limites entre os membros do grupo e os indivíduos não pertencentes a ele.
As relações de identidade estão mais vinculadas no contato entre os membros do grupo e o seu líder, seguindo Freud, Ernesto Laclau aponta uma ligação de característica libidinal entre o líder e os membros do grupo.

Mais uma vez, vale destacar, o autor evita apontar esta característica como um elemento negativo, ou de irracionalidade, prejudicial ao reconhecimento desta ligação, inclusive em seus aspectos libidinais.

No referente a análise dos discursos, o autor aponta dois elementos verificáveis nos mais variados contextos reconhecidos como populistas, os significantes vazios e os significantes flutuantes.

A despeito de todas estas contribuições anteriormente mencionadas, o conceito de significante vazio merece uma atenção especial na análise do autor. Considerando a heterogeneidade social e política, a construção do povo remete à uma universalidade muito difícil de ser obtida na prática. No entanto, o autor não descarta a sua importância enquanto horizonte do discurso.

Assim, o autor reconhece a possibilidade de criação do povo desde que exista clareza quanto às estratégias discursivas usadas pelos governantes.

Ernesto Laclau retoma o conceito de hegemonia para indicar a busca pela universalidade do discurso enquanto horizonte, neste aspecto os significantes vazios terão uma função essencial de dar amplitude ao discurso de modo que o maior número de destinatários se sinta abrangido pelo conteúdo do discurso (LACLAU; MOUFFE, 2006).

Assim, a ausência de um conteúdo fixo, ou mesmo sectário, do discurso populista, que muitas vezes é indicado como sua fragilidade, é apresentada pelo autor como um elemento fundamental à abrangência dos destinatários que se sentem contemplados pelo seu conteúdo, muitas vezes marcado pela sugestionabilidade, pela ausência de rigor conceitual, e até mesmo falta de significado previamente definido.

Deste modo, o significante vazio pode ser preenchido por critérios de nacionalidade, elementos étnicos, o amor ao povo, um mito fundador daquela sociedade, entre outros. Considerando os contextos de grande amplitude deste tipo de discurso, os significantes vazios propositalmente não passam por um rigor conceitual rigoroso, segundo Laclau análises deste tipo ensejariam o surgimento de sectarismos entre os integrantes do grupo receptor destas mensagens.

Conforme demonstraremos até o final desta resenha, a novidade da análise de Ernesto Laclau está em reconhecer que os significantes vazios não são, necessariamente, preenchidos por elementos negativos, ou que propiciem uma manipulação do eleitorado.

Até o ponto de identificação da ausência de um conteúdo fixo nos discursos populistas e do seu 
preenchimento por aspectos considerados negativos grande parte da doutrina já havia chegado, a inovação do autor reside na indicação que estes significantes vazios podem ser preenchidos por elementos consensuais de um paradigma do Estado Democrático de Direito contemporâneo, como a garantia dos direitos humanos, a legitimação democrática do poder dos governantes, entre outros.

$\mathrm{Na}$ análise de Laclau, o significante vazio será responsável pela criação de uma cadeia de equivalência, isto é, o elemento do discurso explicativo e aceito como responsável pela formação do grupo, o que o autor vai identificar com o surgimento da identidade popular quando aplicado em larga escala.

Figura complementar dos significantes vazios são os significantes flutuantes, que na perspectiva desenvolvida terão a função de identificar eventuais mudanças no significante vazio como estratégia para a manutenção da eficiência do discurso na criação e condução do grupo.

Nos estudos desenvolvidos, Laclau identifica que a consolidação do conteúdo discursivo pode ensejar o surgimento de sectarismos que dificultam o surgimento e ou manutenção do grupo já constituído.

Estruturalmente, os significantes flutuantes possibilitam a análise destes ajustes do discurso essenciais à criação ou manutenção do grupo. Como exemplo, o autor analisa os discursos de implementação do Estado de Bem-Estar Social nos Estados Unidos da América das primeiras décadas do século XX, e suas mudanças até o desenvolvimento de um anti-comunismo difuso na sociedade norte-americana nas décadas seguintes.

Assim, o significantes vazios e os significantes flutuantes serão essenciais para garantir adaptabilidade à grande variedade de demandas sociais e a seu dinâmico processo político.

O ultimo elemento a ser analisado por Ernesto Laclau é a relação entre heterogeneidade e a criação de um povo, a questão se apresenta relevante porque em um primeiro momento a concepção de constituição de um povo foi marcada por um viés de integridade.

Em função desta forte tendência de uma concepção do povo a partir de critérios monolíticos a fórmula jurídica de que todo poder emana do povo foi projetada a partir de critérios uniformes, o que ensejou a busca pelo arianismo, ou interpretações extremistas de movimentos nacionalistas.

Tal tendência invariavelmente afastou a organização do Estado dos postulados democráticos, disto deriva a importância da análise desenvolvida por Laclau entre heterogeneidade e constituição do povo.

$\mathrm{O}$ autor insere os conceitos de representação e demanda como elementos para intermediação entre a heterogeneidade e a constituição do povo, o desafio colocado constitui-se entre estabelecer estes parâmetros sem tender para concepções monolíticas e excludentes de um parâmetro de organização social pluralista.

Laclau indica a pertinência dos institutos de representação funcionar como meios de encaminhamento das demandas necessárias à constituição de um povo. Analisando o trabalho de Hannah Pitkin e de Claude Lefort, o autor critica as concepções ordinárias nas Teorias da Representação política que reconhecem a existência da vontade do povo antes do exercício da representação.

A interpretação de que existe uma vontade do povo anterior a representação seria um fator determinante para o surgimento de intérpretes exclusivos desta vontade e os riscos autoritários e totalitários desta interpretação.

Ernesto Laclau indica que esta interpretação não é uma fatalidade, caso seja possível o reconhecimento da vontade do povo como constituída a partir da representação ocorrerá a possibilidade da constituição de uma vontade do povo a partir dos parâmetros qualitativos de uma perspectiva democrática, com respeito aos direitos humanos, ao pluralismo político e à heterogeneidade.

Neste contexto, uma inovação substantiva da análise do autor está em reconhecer que a dimensão simbólica e afetiva na constituição de um grupo não é, necessariamente, refratária à uma organização democrática.

Junto com Chantal Mouffe o texto enfoca a importância destes elementos até então marginalizados pelas Teorias Políticas da Democracia para a constituição de um regime com qualidade.

Se a existência de um símbolo já era reconhecida como prioritária em trabalhos de Pitkin e Leford, Ernesto Laclau vai apontar que isto não é negativo, apresentando-se, pelo contrário, como elemento indissociável de uma perspectiva democrática em relação ao futuro.

$\mathrm{Na}$ proposta apresentada os significantes vazios exercem uma função essencial ao se reconhecer a impossibilidade de organizar e manter um povo, dentro de parâmetros democráticos, com um conteúdo discursivo fixo e imutável. Tal metodologia teria tendências autoritárias, na medida em que a dinâmica social e política escapam à fixação conceitual pretendida.

Segundo o autor, os significantes vazios seriam o correspondentes da incompletude inerente à dinâmica social. Visando evitar as tendências dos significantes vazios serem utilizados como instrumentos discursivos negativos torna-se necessário o seu vinculo de forma inexorável à pauta da garantia dos direitos humanos como também aos postulados do Estado Democrático de Direito. 
Com isto podemos assinalar que as principais contribuições ao debate sobre populismo feitas por Ernesto Laclau nesta obra estão relacionadas ao seu afastamento de uma interpretação exclusivamente negativa do fenômeno, a sua qualificada análise discursiva, e a identificação de elementos que estão presentes também nos regimes democráticos de forma incontornável. Segundo o autor, a inserção dos símbolos, da libido e da afetividade, são elementos imprescindíveis na qualificação da democracia.

Conforme apresentou Chantal Mouffe recentemente, a análise de Laclau reconhece a importância de um elemento populista para a qualificação das democracias contemporâneas (MOUFFE, 2015). Na última parte da obra o autor vai apresentar vários contextos que foram identificados com o populismo, estabelecendo, ainda, diálogos, com autores contemporâneos com o Slavov Zizek, Michael Hardt, Antonio Negri e Jacques Ranciere, aproximando-se expressamente do pensamento deste último.

Com o texto bastante avançado, Ernesto Laclau apresenta os elementos para a sua revisão do conceito de populismo, baseado nos pilares dispostos anteriormente: seja no referente as relações internas, de equivalência e de identidade, seja em relação a composição do discurso, com os significantes vazios e os significantes flutuantes; e, por fim, nas relações entre heterogeneidade e constituição de um povo.
O livro apresenta uma nova perspectiva sobre o que se denomina de populismo, certamente tem muito a contribuir na discussão da matéria, abrindo um sem número de possibilidades analíticas, sendo de se lamentar, apenas, o falecimento recente do autor em um momento tão produtivo da sua carreira.

\section{Referências}

GOMES, A. C. O populismo e as ciências sociais no Brasil: notas sobre a trajetória de um conceito. Tempo, v. 1, n. 2, p. 31-58, 1996.

LACLAU, E. A razão populista. Três estrelas: São Paulo, 2013.

LACLAU, E.; MOUFFE, C. Hegemonía y estrategia socialista: hacia una radicalización de la democracia. 2. ed. Buenos Aires: Fondo de Cultura Economica de Argentina, 2006.

MOUFFE, C. Hay uma necessária dimensión populista em La democracia. El pais, 2015. Disponível em: $<$ http://politica.elpais.com/politica/2015/04/17/ actualidad/1429290307_967426.html >. Acesso em: 24 abr. 2015.

Recebido: 06 ago., 2015 Aceito: 26 out., 2015 